\title{
Review of autoantigens in Sjögren's syndrome: an update
}

This article was published in the following Dove Press journal:

Journal of Inflammation Research

7 August 2017

Number of times this article has been viewed

\section{Louis Tong ${ }^{1-4}$ \\ Vanessa Koh ${ }^{3}$ \\ Bernard Yu-Hor Thong 5 \\ 'Department of Ophthalmology, Yong Loo Lin School of Medicine, National University of Singapore, ${ }^{2}$ Corneal and External Eye Disease, Singapore National Eye Centre, ${ }^{3}$ Ocular Surface Research Group, Singapore Eye Research Institute, ${ }^{4}$ Eye Academic Clinical Program, Duke-NUS Medical School, ${ }^{5}$ Department of Rheumatology, Allergy and Immunology, Tan Tock Seng Hospital, Singapore}

Correspondence: Louis Tong Singapore National Eye Centre, II Third Hospital Avenue, Postcode 16875I, Singapore

Tel +65 62277255

Fax +65 63224599

Email louis.tong.h.t@singhealth.com.sg
Abstract: Primary Sjögren's syndrome (pSS) is an autoimmune disease characterized by inflammation in exocrine glands, resulting in reduced secretion of tears and saliva, manifesting as xerophthalmia and xerostomia, respectively. It is commonly associated with Sjögren's syndrome type A (Ro) and Sjögren's syndrome type B (La) antigens. However, in most patients, the identity of the triggering antigen is not known. Factors such as genetics of histocompatibility, dysregulation of T-cells, B-cells and viral infections have been implicated. Several important studies on autoantigens in pSS have been published since a review in 2012, and the aim of this review is to provide an update on further peer-reviewed original articles in this field. Oxidative damage of Ro60 antigen may explain the epitope spreading during the immune activation in $\mathrm{pSS}$. Immune-mediated destruction of the muscarinic receptor-3-expressing cells has been associated with a reduction in parasympathetic function, which could cause reduced secretory function of exocrine glands. Such a process also activates reactive oxidative species and antioxidants, which are linked to the triggering of inflammatory responses. Elevated levels of kallikrein, yet another antigen present in the lacrimal gland and other tissues, are similarly involved in triggering an autoimmune T-cell response against target glands. Studying additional antigens, the platelet-selectin and vasoactive intestinal peptides, in patients with pSS can help to elucidate the origin and process of autoimmunity, or even lead to potential biomarkers. In conclusion, the understanding of autoantigens has led to exciting major advances in the biology of pSS and may influence diagnosis and management of pSS in future.

Keywords: Sjögren's syndrome, review, ocular disease, autoimmune, autoantigen, inflammation

\section{Autoimmunity and autoantigens}

Under normal circumstances, self-antigens do not activate the immune system. When there is a conformational change in the epitopes of these self-antigens for any reason, eg, somatic mutations/injury (immunoediting concept), or when two antigens that had been spatially separated bind one other (hapten-carrier concept), immune reactivity against self-antigens can increase. Such breaks in immune tolerance may result in autoimmunity, mediated by T- and B-lymphocytes. The T-cells can mount effector cytotoxicity responses, and B-cells can differentiate into plasma cells that produce specific immunoglobulins against the autoantigens. Effector lymphocytes and antibodies then target the tissues expressing the self-antigens and cause damage in those tissues. As a consequence of the damage, other different antigens are likely to be subsequently targeted by secondary immune responses (epitope spreading), which can sustain the autoimmune disease. ${ }^{1}$ 
Based on these considerations, we hypothesize that specific molecular targets of autoantibodies deserve attention by researchers because the clinical manifestations of dysfunctional organs offer an opportunity to elicit the physiological role of the target antigen in the healthy state.

\section{Sjögren's syndrome}

Sjögren's syndrome is a chronic systemic autoimmune epithelitis involving the exocrine glands of the human body, ie, lacrimal and salivary glands. ${ }^{2}$ Primary Sjögren's syndrome (pSS) is a disease entity that is unrelated to the presence of another known autoimmune disease. Secondary Sjögren's syndrome refers to the autoimmune disease affecting the same exocrine glands but that exists as part of another known autoimmune systemic disease such as rheumatoid arthritis. ${ }^{3}$ The overall population prevalence rate of pSS in a meta-analysis was reported to be $6 / 10,000 ;{ }^{4} \mathrm{pSS}$ is known to be associated with significant morbidity, including psychological and social dysfunction. ${ }^{5}$ The autoimmune disease in pSS is triggered by B- and T-lymphocyte-mediated responses against certain antigens, ${ }^{6}$ although the nature of the primary antigen is not fully known, and may vary among individuals with pSS in different reports. More comprehensive reviews of autoantigens in Sjögren's syndrome have been published in $2007^{7}$ and 2012. ${ }^{8}$ At the same time, there was an article reviewing the autoantigens of Sjögren's syndrome in 2017. ${ }^{9}$ However, it did not review recent original papers. Hence, we aim to list the more recently published research not covered by these reports, concerning the autoantigens in pSS (Tables 1 and 2). An initial literature search was also conducted using both PubMed and SciMed Central databases in order to ensure full coverage of all the recently available literature. In addition, based on these latest studies, we attempted to summarize the mechanisms through which autoantigens can lead to clinical disease in pSS (Figure 1). Apart from pSS, autoantigens in systemic lupus erythematosus and antiphospholipid syndrome have also received major research interest in recent years. ${ }^{10,11}$

\section{Ro and La autoantigens}

The Sjögren's syndrome type A (Ro) and Sjögren's syndrome type B (La) antigens in pSS have been researched for many years and their corresponding autoantibodies are known to be elevated in the plasma of patients with pSS. ${ }^{12-14}$ These autoantibodies are used in routine clinical care to diagnose pSS and have been part of international classification criteria for pSS. ${ }^{15,16}$ Ro52 is a transcription modulator and ubiquitin E3 ligase, Ro60 is an RNA-degrading protein, whereas the La antigen is an RNA-binding phosphoprotein. These sub- serve highly conserved roles and are ubiquitous in vertebrate cells. ${ }^{13,14}$

Recently, a study has shed light on when autoantibodies first appear during the course of autoimmunity. During inflammatory states, lymphocytes can accumulate in certain organs, including exocrine glands. When this occurs, the lymphocytes infiltrate the tissues diffusely or as organized aggregates called lymphoid follicles. ${ }^{17}$ Autoantibodies to Ro and La were detected at 8 weeks of age in female mice models (non-obese diabetic mice NOD.H2 ${ }^{\text {h4 }}$ mice) of Sjögren's syndrome. This time point was prior to the appearance of follicular lymphoid changes in the salivary glands, as well as prior to the time of elevation of the less-specific anti-doublestranded DNA (anti-dsDNA) autoantibody in the serum. ${ }^{18}$

At 8 weeks, B-cells located in the germinal centers in the spleen proliferated, resulting in noticeable increases in the size of these structures, and since differentiated B-cells, ie, plasma cells, produce immunoglobulins (Igs), it is highly suggestive that these are the sources of the Ro and La autoantibodies, instead of the lymphoid follicles in the salivary glands. ${ }^{18}$ More studies will be required to examine the site and timing of the initial antigen presentation, as well as how the naïve lymphocytic clone eventually is amplified to form the splenic germinal centers.

During chronic inflammation, the initial autoantigen may be further damaged due to ongoing immune activation. In an interesting recent study, oxidative (4-hydroxy-2-nonenal) modification of the Ro60 antigen has been shown to result in robust T- and B-lymphocyte activation in mice, compared to immunization with unmodified Ro60. The greater the extent of the oxidative modification, the more amplified were the observed T- and B-cell responses. ${ }^{19}$ This may be how epitope spreading occurs in some patients with pSS.

\section{Muscarinic receptors as autoantigens in Sjögren's syndrome}

The muscarinic receptors are seven G-protein-coupled transmembrane glycoproteins that respond to acetylcholine. These receptors subserve neurotransmitter functions in the parasympathetic nervous system, as well as hormonal functions in nonneural tissues such as smooth muscles. ${ }^{20}$ There are, in total, five subtypes of muscarinic receptors (M1R$\mathrm{M} 5 \mathrm{R})$. In the lacrimal glands, binding of the M3 receptor by acetylcholine leads to glandular secretion. ${ }^{21}$ In smooth muscles, M2R and M3R work in concert to initiate contraction. In myoepithelial cells, M3R facilitates the movement of tears in the lacrimal gland ducts. In conjunctival goblet cells, M2 and M3Rs have been implicated in secretion of 
Table I Clinical studies related to antigens in Sjögren's syndrome since 201 I

\begin{tabular}{|c|c|c|c|c|c|c|c|}
\hline Authors & Year & $\begin{array}{l}\text { pSS } \\
\text { number }\end{array}$ & $\begin{array}{l}\text { Control } \\
\text { number }\end{array}$ & $\begin{array}{l}\text { Immune } \\
\text { target }\end{array}$ & $\begin{array}{l}\text { Tissues } \\
\text { evaluated }\end{array}$ & $\begin{array}{l}\text { Analytical } \\
\text { techniques }\end{array}$ & Remarks \\
\hline Gourzi et $\mathrm{al}^{47}$ & 2015 & 29 & $24 *$ & $\mathrm{Ro}^{\ddagger}, \mathrm{La}^{x}$ & $\begin{array}{l}\text { Minor salivary } \\
\text { gland, blood } \\
\text { mononuclear } \\
\text { cells }\end{array}$ & qRT-PCR & $\begin{array}{l}\text { Certain miRNA correlated to levels of Ro and } \\
\text { La. }\end{array}$ \\
\hline Hirose et $\mathrm{al}^{48}$ & 2015 & II & $10 *$ & Ro, La & $\begin{array}{l}\text { Salivary gland } \\
\text { tissues }\end{array}$ & Western blot, ELISA & $\begin{array}{l}\text { Protein-conjugated acrolein higher in saliva } \\
\text { of pSS, acrolein can confer greater activity to } \\
\text { autoantibodies targeting Ro and La. }\end{array}$ \\
\hline $\begin{array}{l}\text { Katsiougiannis } \\
\text { et } \mathrm{al}^{49}\end{array}$ & 2015 & 8 & 4 & Ro, La & $\begin{array}{l}\text { Minor salivary } \\
\text { gland tissues }\end{array}$ & ELISA & $\begin{array}{l}\text { ER stress activated in salivary glands, causes } \\
\text { apoptosis, leading to movement of SSA and SSB } \\
\text { from cytosol to cell membranes. }\end{array}$ \\
\hline $\begin{array}{l}\text { Pertovaara } \\
\text { et } \mathrm{al}^{50}\end{array}$ & 2015 & 16 & 16 & $\mathrm{La}$ & $\begin{array}{l}\text { Plasma } \\
\text { monocytes, } \\
\text { T- and B-cells, } \\
\text { salivary gland } \\
\text { tissue }\end{array}$ & $\begin{array}{l}\text { qRT-PCR, flow } \\
\text { cytometry }\end{array}$ & $\begin{array}{l}\text { Phosphorylation of STAT in blood macrophages } \\
\text { more common in PSS than in controls. }\end{array}$ \\
\hline Aqrawi et a ${ }^{51}$ & 2014 & 28 & 19 & Ro52 & $\begin{array}{l}\text { Salivary gland } \\
\text { tissues, serum }\end{array}$ & ELISA & $\begin{array}{l}\text { Little Ro52 secretion in saliva/serum } \\
\text { but upregulated in ductal epithelium and } \\
\text { mononuclear cell infiltrate in pSS patients }\end{array}$ \\
\hline Zheng et $\mathrm{a}^{52}$ & 2014 & 289 & Nil & $\begin{array}{l}\text { Ro, La, } \\
\text { ANA, } \\
\text { ACA, RF }\end{array}$ & Serum & Not specified & $\begin{array}{l}\text { Categorization of pSS based on clinical parotid } \\
\text { gland features and serology may be useful. Ro60 } \\
\text { may be associated with massive parotid glands. }\end{array}$ \\
\hline Scofield et a $\left.\right|^{53}$ & 2012 & 88 & Nil & Ro, La & Serum & Immunodiffusion & $\begin{array}{l}\text { Sensory neuropathy is associated with the presence } \\
\text { of Ro and La autoantibodies in PSS patients. }\end{array}$ \\
\hline $\begin{array}{l}\text { ter Borg } \\
\text { et a }\left.\right|^{54}\end{array}$ & 2011 & 65 & Nil & $\begin{array}{l}\text { Ro, La, } \\
\text { ANA }\end{array}$ & Plasma & ELISA, Western blot & $\begin{array}{l}\text { Presence of SSA autoantibodies predictor of } \\
\text { extraglandular manifestations of pSS. }\end{array}$ \\
\hline Zuo et $\mathrm{al}^{25}$ & 2016 & 24 & 23 & $M 3 R$ & Plasma & $\begin{array}{l}\text { Western blot, in-cell } \\
\text { Western assay }\end{array}$ & $\begin{array}{l}\text { Higher M3R autoantibodies identified in pSS } \\
\text { patients than in controls. M3R autoantibodies } \\
\text { associated with SSA and SSB. }\end{array}$ \\
\hline Wolska et $\mathrm{a}^{55}$ & 2016 & 235 & 50 & TRIM-38 & Serum & $\begin{array}{l}\text { Quantitative } \\
\text { immunoprecipitation }\end{array}$ & $\begin{array}{l}\text { Anti-TRIM38 significantly associated with classical } \\
\text { autoantigens of pSS and clinical signs such as high } \\
\text { ocular staining and low Schirmer's scores. }\end{array}$ \\
\hline Alam et $\mathrm{a}^{39}$ & 2016 & 102 & 53 & $A q-5$ & Serum & $\begin{array}{l}\text { IIFA, Western } \\
\text { blotting }\end{array}$ & $\begin{array}{l}\text { Anti-aq5 significantly associated with sera in SS } \\
\text { patients than in controls. It is also related to the } \\
\text { resting saliva flow in SS patients. }\end{array}$ \\
\hline Hu et a $\left.\right|^{42}$ & 2015 & 32 & 35 & $\begin{array}{l}\text { Platelet- } \\
\text { selectin }\end{array}$ & Serum & ELISA & $\begin{array}{l}\text { P-Selectin autoantibodies found elevated in pSS } \\
\text { (with and without thrombocytopenia) compared } \\
\text { to healthy controls }\end{array}$ \\
\hline Suresh et $\mathrm{al}^{56}$ & 2015 & 89 & 50 & $\begin{array}{l}\text { SPI, CA6, } \\
\text { PSP }\end{array}$ & Serum & ELISA & $\begin{array}{l}\text { Antigens potentially able to be used to identify pSS } \\
\text { in patients with low focus scores on lip biopsies. }\end{array}$ \\
\hline Reina et $\mathrm{al}^{26}$ & 2015 & 25 & 25 & M3R & Serum & ELISA & Summarized in main text \\
\hline Hauk et $\mathrm{al}^{37}$ & 2014 & 38 & 16 & $\begin{array}{l}\text { VIP } \\
\text { receptor } 2\end{array}$ & $\begin{array}{l}\text { Monocytes } \\
\text { from plasma }\end{array}$ & $\begin{array}{l}\text { Flow cytometry, } \\
\text { ELISA, qRT-PCR }\end{array}$ & $\begin{array}{l}\text { Levels of VIPR differ between PSS and controls. } \\
\text { Response of VIPR expression to LPS also differs. }\end{array}$ \\
\hline $\begin{array}{l}\text { El Annan } \\
\text { et } \mathrm{a}^{43}\end{array}$ & 2013 & 11 & 8 & Kallikrein & Serum & $\begin{array}{l}\text { Antibody capture } \\
\text { assay }\end{array}$ & Anti-KLKII can be used as a biomarker. \\
\hline Shen et a $\mathrm{a}^{40}$ & 2012 & $33^{\mathrm{xx}}$ & 23 & $\begin{array}{l}\text { SPI, CA6, } \\
\text { PSP }\end{array}$ & Serum & ELISA & $\begin{array}{l}\text { Antigens potentially able to identify patients in } \\
\text { the early onset of SS and contribute in identifying } \\
\text { patients who are negative for classical antigens. }\end{array}$ \\
\hline Reina et $\mathrm{a}^{57}$ & 2011 & 17 & 15 & M3R & Serum & ELISA & $\begin{array}{l}\text { M3R induces the production of pro-inflammatory } \\
\text { markers } \text { PGE }_{2} \text { and MMP-3, which can be used as } \\
\text { biomarkers. }\end{array}$ \\
\hline
\end{tabular}

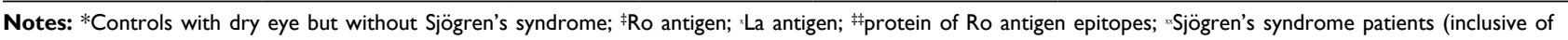
secondary Sjögren's syndrome).

Abbreviations: ACA, anti-centromere antibody; ANA, anti-nuclear antibody; Aq-5, aquaporin-5; CA6, carbonic anhydrase-6; ELISA, enzyme-linked immunosorbent assay; ER, endoplasmic reticulum; IIFA, indirect immunofluorescence assay; KLK, kallikrein; LPS, lipopolysaccharide; M3R, muscarinic receptor-3; PGE2, prostaglandin E2; PSP, parotid secretory protein; pSS, primary Sjögren's syndrome; qRT-PCR, qualitative reverse transcription- polymerase chain reaction; RF, rheumatoid factor; SPI, salivary protein-I; Ro, Sjögren's syndrome Type A; La, Sjögren's syndrome Type B; VIP, vasoactive intestinal peptide; VIPR, VIP receptor. 
Table 2 Studies related to antigens in Sjögren's syndrome (animal research)

\begin{tabular}{|c|c|c|c|c|c|}
\hline Studies & Year & Species & Immune target & Tissues & Intervention \\
\hline Szczerba et al ${ }^{58}$ & 2016 & New Zealand mixed mice & Ro52抹 & $\begin{array}{l}\text { Plasma, salivary } \\
\text { gland tissue }\end{array}$ & Immunization \\
\hline Ding and Zhang ${ }^{59}$ & 2016 & Rabbits & La, ${ }^{x}$ ENA & Plasma & Immunization \\
\hline Szymula et al ${ }^{160}$ & 2014 & HLA-DR3 transgenic mice & Ro60 & Plasma & Nil \\
\hline Karnell et al ${ }^{18}$ & 2014 & NOD mice ${ }^{\triangleleft}$ & Ro, ${ }^{\ddagger}$ La, ${ }^{,}$Ds-DNA ${ }^{* x}$ & $\begin{array}{l}\text { Salivary gland } \\
\text { tissues }\end{array}$ & Nil \\
\hline Al-Majdoub et $\mathrm{al}^{61}$ & 2013 & Rabbits & Ro52 & Plasma & Immunization \\
\hline Kurien et al ${ }^{19}$ & 2011 & BALB/c mice & Ro60㧊 & Plasma & $\begin{array}{l}\text { Immunization with HNE- } \\
\text { Ro60 }\end{array}$ \\
\hline Yang et $\mathrm{a}^{27}$ & 2016 & C57BL/6 Mice & M3R & Lacrimal gland & $\begin{array}{l}\text { Immunization with M3R } \\
\text { peptide }\end{array}$ \\
\hline Hauk et $\mathrm{al}^{37}$ & 2014 & NOD Mice & VIP receptor & Plasma monocytes & $\mathrm{Nil}$ \\
\hline Shen et $\mathrm{al}^{40}$ & 2012 & NOD Mice, IL4 4 TG Mice, C57BL/6 Mice & SPI CA6, PSP & Serum & Nil \\
\hline
\end{tabular}

Notes: 玍 antigen; ‘la antigen; 㧊protein of Ro antigen epitopes; "Ds-DNA, double-stranded DNA antibody.

Abbreviations: CA6, carbonic anhydrase-6; ENA, extractable nuclear antigens; HLA-DR3, human leukocyte antigen - antigen D related-3; M3R, muscarinic receptor-3; NOD, non-obese diabetic mice; PSP, parotid secretory protein; SPI, salivary protein-I; Ro, Sjögren's syndrome Type A; La, Sjögren's syndrome Type B; VIP, vasoactive intestinal peptide.

their mucin contents, and in meibomian glands, muscarinic receptors have been found to regulate meibum secretion..$^{22,23}$

Certain studies have implicated M3R as a potential autoantigen in pSS. ${ }^{20,24}$ Recently, two clinical studies have shown that the immune responses stimulated by M3R could cause the failure of M3R signaling pathways, ultimately leading to the development of $\mathrm{pSS} .{ }^{25,26} \mathrm{M} 3 \mathrm{R}$ peptides are able to activate interferon (IFN)- $\gamma$-reactive T-cells, which then induce inflammation targeting the tissues expressing these peptides.

Yang et $\mathrm{al}^{27}$ described an interesting model of Sjögren's syndrome in mice induced by immunization of a mixture of peptides derived from extracellular loops of M3R. These mice displayed features of inflammation in the lacrimal glands, salivary glands and the intestines. The inflammation was characterized by an increase in CD4 and CD8 T-lymphocytes in the salivary gland and the intestines but by an increase in non-CD4+/non-CD8+ mononuclear cells (MNCs) in the lacrimal glands. Plasma cells were elevated in all three tissues. The inflammation in the salivary glands and intestines, but not the lacrimal glands, was mediated by the cytokines interleukin (IL)-17 and IFN- $\gamma$, which could have originated from the splenocytes that highly expressed these same cytokines. IFN- $\gamma$ may have increased the activation of MNCs or reduced the apoptosis of MNCs, and either scenario would explain the greater infiltration of MNCs into the lacrimal gland. ${ }^{27}$

Activation of MNCs is highly dependent on growth factor signaling, such as that of the epidermal growth factor receptor (EGFR). The expression of antibodies blocking EGFR would reduce the number of activated MNCs. Immunization was performed with a peptide derived from EGFR-blocking antibodies (mimotope immunization [MI]) as well as M3R peptides. This caused the resulting MNCs in the lacrimal gland to reduce in number, and so did the T-lymphocytes in the salivary glands. In these animals, the serum antibodies against EGFR were elevated on Day 38, and their splenocytes produced similar antibodies. At the same time, there was increased Fas expression in MNCs, which could mediate apoptosis and reduce the number of MNCs in the lacrimal gland. The splenocytes obtained from these mice had downregulation of IL-17. Since IL-17 normally stimulates MNC proliferation, this may also explain the reduction of MNCs in the lacrimal glands. ${ }^{27}$

Interestingly, enzyme-linked immunosorbent assay (ELISA) studies showed that increased serum antibodies in mice with additional MI could bind M3R peptides. This may explain why coimmunization with MI and M3R peptides did not significantly improve saliva secretion compared to animals immunized with M3R. The beneficial effects of less immune cell infiltration into the salivary glands may be partly obliterated by the detrimental effect of the cross-reacting antibodies blocking M3R signaling for saliva production. ${ }^{27}$

In another murine study, the antibody to M3R has been reported to increase levels of antioxidants, ie, superoxide dismutase (SOD) and catalase (CAT) ${ }^{26}$ Since dry eye disease in humans has been linked to abnormal antioxidant status, ${ }^{28}$ Reina's study provides a mechanistic link between the M3R autoantigen and the disease mechanism in dry eye disease.

Notwithstanding these considerations, there is controversy concerning the mechanism and effects of autoantibodies on M3Rs in pSS. Some research has found that autoantibodies act like muscarinic agonists, producing effects 


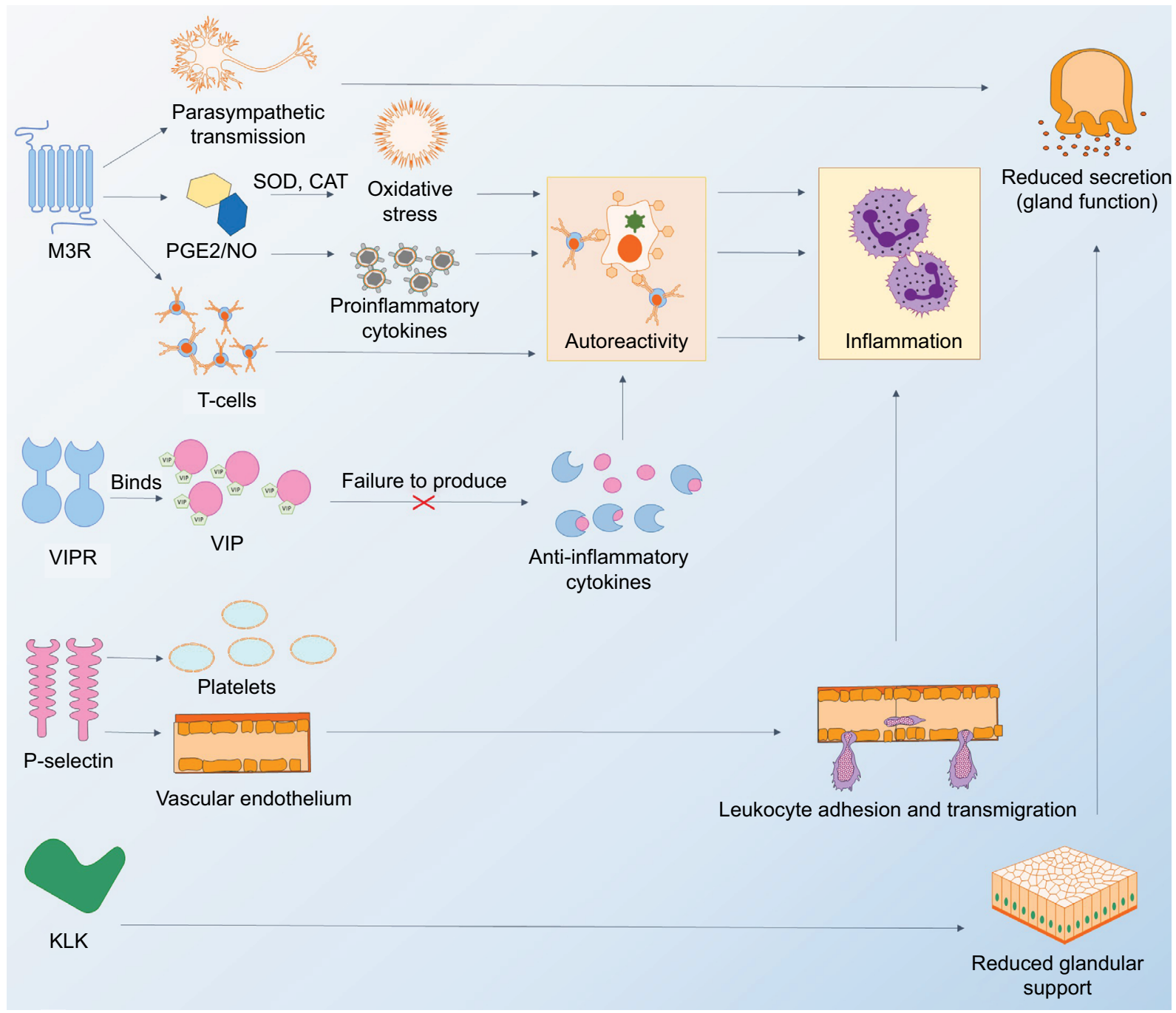

Figure I Diagram showing autoantigens and how disease processes in Sjögren's syndrome depend on autoreactivity against these autoantigens.

Notes: The M3R plays a role in parasympathetic functions by acting as a receptor to neurotransmitters in the nervous system. The dysfunction of this parasympathetic transmission can cause reduced function in gland secretion. The M3R autoantigen, when expressed abnormally, is able to increase levels of PGE2 and NO. It also increases levels of antioxidants such as SOD and CAT. Activated enzymes SOD and CAT are able to induce oxidative stress, causing the destruction and damage of salivary glands in rats, leading to inflammation. Abnormal release of T-cells and/or proinflammatory cytokines induces an autoimmune reaction when T-cells attack host cells (such as acinar cells in salivary or lacrimal glands), resulting in increased inflammation. The VIP binds specifically to its receptor, VIPR, which during normal function, is able to stimulate the production of anti-inflammatory cytokines. The failure to produce these cytokines can also result in an autoreactive response. P-selectin induces platelet activation and is crucial for cell adhesion on the vascular endothelium. Finally, immune-mediated responses against KLK could cause damage to acinar cells in exocrine glands, causing reduced glandular support and secretion. Not shown in figure: carbonic anhydrase-6 and aquaporin-5 may be directly involved in fluid production from the salivary and lacrimal glands, and autoimmune damage is likely to cause reduced secretion.

Abbreviations: CAT, catalase; KLK, kallikrein; M3R, muscarinic receptor subtype 3; NO, nitric oxide; P, platelet; PGE, prostaglandin E; SOD, superoxide dismutase; VIP, vasoactive intestinal peptide; VIPR, vasoactive intestinal peptide receptor.

like the natural ligands of the receptor. ${ }^{62}$ Overstimulation of the M3R increases nitric oxide synthase activity, and the resulting increase in nitric oxide, if excessive, can induce cytotoxicity in the lacrimal gland. ${ }^{24,29}$ Studies have also shown that these autoantibodies act like M3 antagonists and inhibit acetylcholine release. ${ }^{30}$ In a mouse model of Sjögren's syndrome, there was retention of goblet cell secretions as well as reduced M3R expression in these cells, suggesting that the autoantibodies played an M3R antagonistic role or indirectly opposed muscarinic receptor signaling by reducing the numbers of M3Rs. ${ }^{31}$

\section{Other autoantigens in Sjögren's syndrome}

Vasoactive intestinal peptide (VIP) is a neuropeptide and hormone from the glucagon family that binds to VIP receptor (VIPR) 1 and 2 on target cells, ie, immune cells, smooth muscles, as well as lung and intestinal epithelial cells. ${ }^{32}$ 
By binding to VIPR, VIP is also able to induce immunemodulatory effects ${ }^{32}$ on monocytes, macrophages and T-cells. It has anti-inflammatory effects, as it inhibits proinflammatory cytokines, such as tumor necrosis factor (TNF)- $\alpha$ and IL-6, ${ }^{33-35}$ and upregulates the anti-inflammatory cytokine IL-10. ${ }^{34-36}$ However, a recent study ${ }^{37}$ has shown that exogenous VIP did not change TNF and IL-10 levels expressed by cultured MNCs that had phagocytosed apoptotic salivary gland cells obtained from pSS patients. This study did not evaluate cytokine changes in MNCs from pSS patients under other conditions. ${ }^{37}$

The VIPRs are found in lacrimal glands, where they promote the secretion of proteins, water and electrolytes. They are translated in the endoplasmic reticulum and are then modified and stored in the Golgi body within endoplasmic granules. When specific signals in the form of second messengers are activated, these granules migrate to the cell membranes, enabling functioning VIPRs to be incorporated in the cell surface. VIPRs are also co-regulated by cholinergic agonists. ${ }^{38}$ Although the function of VIPRs is unclear in meibomian glands, ${ }^{22,23}$ exogenous VIP can stimulate increase in intracellular calcium. ${ }^{22}$ The expression of VIPR2 was recently found to be increased in monocytes from pSS patients, but unfortunately, VIPR levels were not assessed in lacrimal and meibomian glandular tissues. ${ }^{37}$

Lipopolysaccharide (LPS) stimulates cells via innate toll-like receptors to influence many immune genes. ${ }^{36}$ In such activated monocytes derived from pSS patients, VIPR2 was observed to be upregulated, compared to activated monocytes from healthy controls. More interestingly, the levels of VIPR2 in pSS monocytes were restored to normal when VIP was added to the activated monocytes. ${ }^{37}$ This reduction of VIPR2 in pSS may potentially reduce any downstream cytokine effects triggered by VIP, including those that exert anti-inflammatory effects.

Recently, original articles studying the role of aquaporins (Aqs) and carbonic anhydrases (CAs) have been published. ${ }^{39,40}$ Aqs are a group of water channels found in various cell types, including the lacrimal and salivary acinar cells, which suggest that autoimmune targeting of these membrane proteins may cause reduced tear and saliva production, respectively. ${ }^{39} \mathrm{Aq}-5$, in particular, has recently been recently emphasized due to its link to the clinical manifestations of Sjögren's syndrome. ${ }^{39}$ The resulting reduction of exocrine functions as mentioned earlier is highly suggestive of the dysfunction of Aq-5. The CA enzymes are critical for ionic exchange in acinar cells. These convert carbon dioxide and bicarbonate to maintain $\mathrm{pH}$, and in the renal tubules, they promote water loss through urine. In pSS, it is likely that damage to CA-6, a member of the CA family, reduces fluid transport into the acinar cavity and therefore the secretion of saliva or tear fluid. ${ }^{40}$

Another potential autoantigen is platelet ( $p$ )-selectin, a $140 \mathrm{kDa}$ protein found in the granules of platelets and vascular endothelial cells. This protein can bind to sialylated Lewis blood group carbohydrate antigens or high-affinity receptors of p-selectins on immune cells such as neutrophils and monocytes. During inflammation, p-selectin can be released from the platelet granules into the plasma. ${ }^{41}$ Recently, p-selectin autoantibodies have been found to be elevated in $\mathrm{pSS}$ patients (with and without thrombocytopenia) compared to healthy controls. ${ }^{42}$ This suggests that even in pSS patients without platelet deficiency, $\mathrm{p}$-selectin could play a role in the disease. It is possible that p-selectin increased the adhesion of immune cells to the walls of blood vessels within exocrine glands and facilitated leukocyte trafficking out of blood vessels during inflammation.

A class of small plasma peptidases called kallikreins (KLKs) has also been implicated in $\mathrm{pSS}^{43}$ and experimental dry eye. ${ }^{44} \mathrm{~A}$ recent study has shown that a particular subtype of KLKs, KLK11, is elevated in humans with Sjögren's syndrome compared to dry eye patients without Sjögren's syndrome, or compared to age- and gender-matched healthy controls. However, in this study. the proportion of pSS patients in the Sjögren's syndrome group has not been reported. What is interesting is that KLK11 is not one of the many KLK subtypes reported in previous pSS patients and mouse models of dry eye. ${ }^{43}$ KLK11 is located in the Golgi apparatus of saliva-producing acinar cells in the salivary glands. ${ }^{45}$ Immune-mediated targeting of KLK11 would therefore destroy the subcellular structure that secretes saliva. Anti-KLK antibodies may thus destroy sufficient glandular acini to reduce secretion. It is unclear at the moment which subtype of KLKs can be used as a marker to determine the severity and/or presence of $\mathrm{pSS} .{ }^{46}$

Sex hormones may play a role in regulation of KLKs, but the changes may or may not be occurring through hormone receptors. ${ }^{46}$ It is not known whether the hormonal effects are relevant to $\mathrm{pSS}$, which is more common in females. KLKs activate bradykinin by cleaving kininogen, and this is a very important process in inflammation, but it is unclear whether KLKs play such a role in pSS. KLKs may just be secondary antigens resulting from epitope spreading.

\section{Limitations and future directions}

Future challenges include the evaluation of the autoantibodies against the proposed autoantigens in larger samples of 
patients. Many of the cited studies only evaluated salivary glands, ${ }^{37,43}$ so more work should be done involving lacrimal and meibomian glands, in addition to analyzing the secretory function of these glands. Future studies should also be performed with epitope mapping of the members of the KLK protein family and to explain the involvement of specific subtypes of KLKs. In terms of using autoantibodies as diagnostic markers for pSS in clinics, more work should be done on the performance of test panels that include these assays compared to the conventional assays against Ro and La autoantibodies.

\section{Conclusion}

Patients with pSS battle a systemic autoimmune disease triggered by a variety of autoantigens. Despite advances in the past few years, the sequence of activation of immunity against these antigens and the relative importance of these antigens remain unknown. It is difficult to determine the primary event from secondary processes in a patient with well-established pSS.

Whenever new autoantigens are discovered or implicated in pSS, it is important to elucidate their physiological function and signaling role in healthy persons. This may lead to a more comprehensive understanding of disease development and progression. Understanding the biological pathways in disease development will help to develop more precise and accurate diagnostic tools and more effective and targeted therapies for these patients.

\section{Acknowledgment}

This study was supported by the National Medical Research Council, Singapore, under grant number NMRC CSA $\backslash 045 \backslash 2012$.

\section{Disclosure}

The authors report no conflicts of interest in this work.

\section{References}

1. van Kempen TS, Wenink MH, Leijten EF, Radstake TR, Boes M. Perception of self: distinguishing autoimmunity from autoinflammation. Nat Rev Rheumatol. 2015;11(8):483-492.

2. Kivity S, Arango MT, Ehrenfeld M, et al. Infection and autoimmunity in Sjogren's syndrome: a clinical study and comprehensive review. J Autoimmun. 2014;51:17-22.

3. Patel R, Shahane A. The epidemiology of Sjögren's syndrome. Clin Epidemiol. 2014;6:247-255.

4. Qin B, Wang J, Yang Z, et al. Epidemiology of primary Sjogren's syndrome: a systematic review and meta-analysis. Ann Rheum Dis. 2015;74(11): 1983-1989.

5. Segal B, Bowman SJ, Fox PC, et al. Primary Sjögren's Syndrome: health experiences and predictors of health quality among patients in the United States. Health Qual Life Outcomes. 2009;7(1):46.
6. Pers JO, Youinou P. Are the B cells cast with the leading part in the Sjogren's syndrome scenario? Oral Dis. 2014;20(6):529-537.

7. Routsias JG, Tzioufas AG. Sjogren's syndrome - study of autoantigens and autoantibodies. Clin Rev Allergy Immunol. 2007;32(3):238-251.

8. Bournia VK, Vlachoyiannopoulos PG. Subgroups of Sjogren syndrome patients according to serological profiles. J Autoimmun. 2012;39(1-2):15-26.

9. Sandhu P, Ambrus JL. Novel autoantibodies in Sjogren syndrome. J Immunol Clin Res. 2017;4(1):1034-1037.

10. Andreoli L, Fredi M, Nalli C, Franceschini F, Meroni PL, Tincani A. Antiphospholipid antibodies mediate autoimmunity against dying cells. Autoimmunity. 2013;46(5):302-306.

11. Zhu H, Luo H, Yan M, Zuo X, Li QZ. Autoantigen microarray for highthroughput autoantibody profiling in systemic lupus erythematosus. Genomics Proteomics Bioinformatics. 2015;13(4):210-218.

12. Toker E, Yavuz Ş, Direskeneli H. Anti-Ro/SSA and anti-La/SSB autoantibodies in the tear fluid of patients with Sjögren's syndrome. $\mathrm{Br} J$ Ophthalmol. 2004;88(3):384-387.

13. Jonsson R, Theander E, Sjostrom B, Brokstad K, Henriksson G. Autoantibodies present before symptom onset in primary Sjogren syndrome. JAMA. 2013;310(17):1854-1855.

14. Theander E, Jonsson R, Sjostrom B, Brokstad K, Olsson P, Henriksson G. Prediction of Sjogren's syndrome years before diagnosis and identification of patients with early onset and severe disease course by autoantibody profiling. Arthritis Rheumatol. 2015;67(9): 2427-2436.

15. Mekinian A, Nicaise-Roland P, Chollet-Martin S, Fain O, Crestani B. Anti-SSA Ro52/Ro60 antibody testing by immunodot could help the diagnosis of Sjogren's syndrome in the absence of anti-SSA/SSB antibodies by '. Rheumatology (Oxford). 2013;52(12):2223-2228.

16. Vitali C, Bombardieri S, Jonsson R, et al. Classification criteria for Sjögren's syndrome: a revised version of the European criteria proposed by the American-European Consensus Group. Ann Rheum Dis. 2002;61(6): $554-558$.

17. Jones GW, Jones SA. Ectopic lymphoid follicles: inducible centres for generating antigen-specific immune responses within tissues. Immunology. 2016;147(2):141-151.

18. Karnell JL, Mahmoud TI, Herbst R, Ettinger R. Discerning the kinetics of autoimmune manifestations in a model of Sjogren's syndrome. Mol Immunol. 2014;62(2):277-282.

19. Kurien BT, Porter A, Dorri Y, et al. Degree of modification of Ro60 by the lipid peroxidation by-product 4-hydroxy-2-nonenal may differentially induce Sjogren syndrome or systemic lupus erythematosus in BALB/c mice. Free Radic Biol Med. 2011;50(10):1222-1233.

20. Mahmoud TI, Wang J, Karnell JL, et al. Autoimmune manifestations in aged mice arise from early-life immune dysregulation. Sci Transl Med. 2016;8(361):361ra137.

21. Kruse AC, Hu J, Pan AC, et al. Structure and dynamics of the M3 muscarinic acetylcholine receptor. Nature. 2012;482(7386):552-556.

22. Kam WR, Sullivan DA. Neurotransmitter influence on human meibomian gland epithelial cells. Invest Ophthalmol Vis Sci. 2011;52(12): 8543-8548.

23. Zhu HY, Riau AK, Barathi VA, Chew J, Beuerman RW. Expression of neural receptors in mouse meibomian gland. Cornea. 2010;29(7):794-801.

24. Bacman S, Perez Leiros C, Sterin-Borda L, Hubscher O, Arana R, Borda E. Autoantibodies against lacrimal gland M3 muscarinic acetylcholine receptors in patients with primary Sjogren's syndrome. Invest Ophthalmol Vis Sci. 1998;39(1):151-156.

25. Zuo J, Williams AE, Park YJ, et al. Muscarinic type 3 receptor autoantibodies are associated with anti-SSA/Ro autoantibodies in Sjogren's syndrome. J Immunol Methods. 2016;437:28-36.

26. Reina S, Rodriguez M, Stranieri G, Borda E. Action of anti-M(3)muscarinic acetylcholine receptor IgG of primary Sjogren's syndrome on the enzymatic antioxidant system in rat submandibular gland. J Oral Pathol Med. 2015;44(10):876-883. 
27. Yang L, Wang Y, Xing R, et al. Mimotope mimicking epidermal growth factor receptor alleviates mononuclear cell infiltration in exocrine glands induced by muscarinic acetylcholine 3 receptor. Clin Immunol. 2016;163:111-119.

28. Sharma A, Hindman HB. Aging: a predisposition to dry eyes. $J$ Ophthalmol. 2014;2014:781683.

29. Bacman SR, Berra A, Sterin-Borda L, Borda ES. Human primary Sjogren's syndrome autoantibodies as mediators of nitric oxide release coupled to lacrimal gland muscarinic acetylcholine receptors. Curr Eye Res. 1998;17(12):1135-1142.

30. Waterman SA, Gordon TP, Rischmueller M. Inhibitory effects of muscarinic receptor autoantibodies on parasympathetic neurotransmission in Sjogren's syndrome. Arthritis Rheum. 2000;43(7):1647-1654.

31. Diebold Y, Chen LL, Tepavcevic V, Ferdman D, Hodges RR, Dartt DA. Lymphocytic infiltration and goblet cell marker alteration in the conjunctiva of the MRL/MpJ-Fas(lpr) mouse model of Sjogren's syndrome. Exp Eye Res. 2007;84(3):500-512.

32. Ganea D, Hooper KM, Kong W. The neuropeptide vasoactive intestinal peptide: direct effects on immune cells and involvement in inflammatory and autoimmune diseases. Acta Physiol (Oxf). 2015;213(2):442-452.

33. Delgado M, Martinez C, Pozo D, et al. Vasoactive intestinal peptide (VIP) and pituitary adenylate cyclase-activation polypeptide (PACAP) protect mice from lethal endotoxemia through the inhibition of TNFalpha and IL-6. J Immunol. 1999;162(2):1200-1205.

34. Delgado M, Abad C, Martinez C, et al. Vasoactive intestinal peptide in the immune system: potential therapeutic role in inflammatory and autoimmune diseases. J Mol Med (Berl). 2002;80(1):16-24.

35. Ganea D, Hooper KM, Kong W. The neuropeptide vip: direct effects on immune cells and involvement in inflammatory and autoimmune diseases. Acta Physiol (Oxf). 2015;213(2):442-452.

36. Delgado M, Munoz-Elias EJ, Gomariz RP, Ganea D. Vasoactive intestinal peptide and pituitary adenylate cyclase-activating polypeptide enhance IL-10 production by murine macrophages: in vitro and in vivo studies. J Immunol. 1999;162(3):1707-1716.

37. Hauk V, Fraccaroli L, Grasso E, et al. Monocytes from Sjogren's syndrome patients display increased vasoactive intestinal peptide receptor 2 expression and impaired apoptotic cell phagocytosis. Clin Exp Immunol. 2014;177(3):662-670.

38. Dartt DA. Signal transduction and control of lacrimal gland protein secretion: a review. Curr Eye Res. 1989;8(6):619-636.

39. Alam J, Koh JH, Kim N, et al. Detection of autoantibodies against aquaporin-5 in the sera of patients with primary Sjögren's syndrome. Immunol Res. 2016;64(4):848-856.

40. Shen L, Suresh L, Lindemann M, et al. Novel autoantibodies in Sjogren's syndrome. Clin Immunol. 2012;145(3):251-255.

41. McEver RP. Selectins: initiators of leucocyte adhesion and signalling at the vascular wall. Cardiovasc Res. 2015;107(3):331-339.

42. Hu YH, Zhou PF, Long GF, et al. Elevated plasma P-selectin autoantibodies in primary Sjogren syndrome patients with thrombocytopenia. Med Sci Monit. 2015;21:3690-3695.

43. El Annan J, Jiang G, Wang D, Zhou J, Foulks GN, Shao H. Elevated immunoglobulin to tissue KLK11 in patients with Sjogren syndrome. Cornea. 2013;32(5):e90-e93.

44. Stern ME, Schaumburg CS, Siemasko KF, et al. Autoantibodies contribute to the immunopathogenesis of experimental dry eye disease. Invest Ophthalmol Vis Sci. 2012;53(4):2062-2075.

45. Bendayan M, Orstavik TB. Immunocytochemical localization of kallikrein in the rat exocrine pancreas. J Histochem Cytochem. 1982;30(1):58-66.

46. Lawrence MG, Lai J, Clements JA. Kallikreins on steroids: structure, function, and hormonal regulation of prostate-specific antigen and the extended kallikrein locus. Endocr Rev. 2010;31(4):407-446.
47. Gourzi VC, Kapsogeorgou EK, Kyriakidis NC, Tzioufas AG. Study of microRNAs (miRNAs) that are predicted to target the autoantigens Ro/ SSA and La/SSB in primary Sjogren's Syndrome. Clin Exp Immunol. 2015;182(1):14-22.

48. Hirose T, Saiki R, Uemura T, et al. Increase in acrolein-conjugated immunoglobulins in saliva from patients with primary Sjogren's syndrome. Clin Chim Acta. 2015;450:184-189.

49. Katsiougiannis S, Tenta R, Skopouli FN. Endoplasmic reticulum stress causes autophagy and apoptosis leading to cellular redistribution of the autoantigens Ro/Sjogren's syndrome-related antigen A (SSA) and $\mathrm{La} / \mathrm{SSB}$ in salivary gland epithelial cells. Clin Exp Immunol. 2015;181(2):244-252.

50. Pertovaara M, Silvennoinen O, Isomaki P. STAT-5 is activated constitutively in T cells, B cells and monocytes from patients with primary Sjogren's syndrome. Clin Exp Immunol. 2015;181(1):29-38.

51. Aqrawi LA, Kvarnstrom M, Brokstad KA, Jonsson R, Skarstein K, Wahren-Herlenius M. Ductal epithelial expression of Ro52 correlates with inflammation in salivary glands of patients with primary Sjogren's syndrome. Clin Exp Immunol. 2014;177(1):244-252.

52. Zheng L, Yu C, Yang C, Xie L, Shi H, Wang Z. The serological profiles of subgroup of primary Sjogren's syndrome correlation with the clinical features of parotid glands. J Craniomaxillofac Surg. 2014;42(7): $1260-1264$

53. Scofield AK, Radfar L, Ice JA, et al. Relation of sensory peripheral neuropathy in Sjogren syndrome to anti-Ro/SSA. J Clin Rheumatol. 2012;18(6):290-293.

54. ter Borg EJ, Risselada AP, Kelder JC. Relation of systemic autoantibodies to the number of extraglandular manifestations in primary Sjogren's Syndrome: a retrospective analysis of 65 patients in the Netherlands. Semin Arthritis Rheum. 2011;40(6):547-551.

55. Wolska N, Rybakowska P, Rasmussen A, et al. Brief report: patients with primary Sjögren's syndrome who are positive for autoantibodies to tripartite motif-containing protein 38 show greater disease severity. Arthritis Rheumatol. 2016;68(3):724-729.

56. Suresh L, Malyavantham K, Shen L, Ambrus JL. Investigation of novel autoantibodies in Sjogren's syndrome utilizing Sera from the Sjogren's international collaborative clinical alliance cohort. BMC Ophthalmol. 2015;15:38.

57. Reina S, Sterin-Borda L, Passafaro D, Borda E. Anti-M(3) muscarinic cholinergic autoantibodies from patients with primary Sjogren's syndrome trigger production of matrix metalloproteinase-3 (MMP-3) and prostaglandin E(2) (PGE(2)) from the submandibular glands. Arch Oral Biol. 2011;56(5):413-420.

58. Szczerba BM, Kaplonek P, Wolska N, et al. Interaction between innate immunity and Ro52-induced antibody causes Sjogren's syndrome-like disorder in mice. Ann Rheum Dis. 2016;75(3):617-622.

59. Ding M, Zhang J. Epitope spreading induced by immunization with synthetic SSB peptides. Exp Ther Med. 2016;12(1):147-150.

60. Szymula A, Rosenthal J, Szczerba BM, Bagavant H, Fu SM, Deshmukh US. T cell epitope mimicry between Sjogren's syndrome antigen A (SSA)/Ro60 and oral, gut, skin and vaginal bacteria. Clin Immunol. 2014;152(1-2):1-9.

61. Al-Majdoub M, Koy C, Lorenz P, Thiesen HJ, Glocker MO. Mass spectrometric and peptide chip characterization of an assembled epitope: analysis of a polyclonal antibody model serum directed against the Sjogren/systemic lupus erythematosus autoantigen TRIM21. J Mass Spectrom. 2013;48(6):651-659.

62. Reina S, Borda E. Autoantibodies against Muscarinic Acetylcholine Receptor on Exocrine Glands in Sjögren Syndrome. Dentistry. $2014 ; 4: 265$ 
The Journal of Inflammation Research is an international, peer-reviewed open access journal that welcomes laboratory and clinical findings on the molecular basis, cell biology and pharmacology of inflammation including original research, reviews, symposium reports, hypothesis formation and commentaries on: acute/chronic inflammation; mediators of

Submit your manuscript here: https://www.dovepress.com/journal-of-inflammation-research-journa

inflammation; cellular processes; molecular mechanisms; pharmacology and novel anti-inflammatory drugs; clinical conditions involving inflammation. The manuscript management system is completely online and includes a very quick and fair peer-review system. Visit http://www.dove press.com/testimonials.php to read real quotes from published authors. 